\title{
Zebra body myopathy
}

INSERM

\section{Source}

INSERM. (1999). Orphanet: an online rare disease and orphan drug data base. Zebra body myopathy. ORPHA:97240

Zebra body myopathy is a benign congenital myopathy, characterised by congenital hypotonia and weakness. Prevalence is unknown. Less than ten patients have been described so far. Muscle biopsy shows zebra bodies and other myopathic changes. Mutations of the alpha-skeletal actin (ACTA1) gene may be involved. 